\title{
Biodiesel and FAME synthesis assisted by microwaves: Homogeneous batch and flow processes
}

\author{
J. Hernando, P. Leton, M.P. Matia, J.L. Novella, J. Alvarez-Builla * \\ Planta Piloto de Química Fina, Universidad de Alcala, 28871 Alcala de Henares, Madrid, Spain
}

Received 8 September 2006; received in revised form 31 October 2006; accepted 2 November 2006

Available online 30 November 2006

\begin{abstract}
Fatty acids methyl esters (FAME) have been prepared under microwave irradiation, using homogeneous catalysis, either in batch or in a flow system. The quality of the biodiesel obtained has been confirmed by GC analysis of the isolated product. While the initial experiments have been performed in a small scale laboratory batch reactor, the best experiment has been straightforward converted into a stop-flow process, by the use of a microwave flow system. Compared with conventional heating methods, the process using microwaves irradiation proved to be a faster method for alcoholysis of triglycerides with methanol, leading to high yields of FAME.
\end{abstract}

(C) 2006 Elsevier Ltd. All rights reserved.

Keywords: Biodiesel; FAME; Microwaves

\section{Introduction}

The transesterification of natural triglycerides (e.g. oils and fats) is employed to obtain fatty acid methyl esters (FAME) which are key reagents in the chemical industry [1-4]. The FAME are the raw materials for the production of long chain carboxylic acids, detergents, alternative fuels for diesel engines (biodiesel) and mono and diglycerides, employed as additives for foods, cosmetics and pharmaceuticals [5]. Biodiesels are biodegradable and non-toxic and have lower $\mathrm{CO}$ and hydrocarbon emissions than petroleum-based diesel when burned [6,7]. They present, however, other technical challenges such as low cloud points and elevated $\mathrm{NO}_{x}$ emissions [8].

The most commonly used technology for triglycerides transesterification is based on the use of batch processes, in which a basic homogeneous catalyst is used $(\mathrm{NaOH}$ or $\mathrm{NaOMe}$ ) and, at the end of the reaction, the catalyst is neutralised $[9,10$, as recent examples]. A continuous transeste-

\footnotetext{
* Corresponding author.

E-mail address: julio.alvarez@uah.es (J. Alvarez-Builla).
}

rification process would be a good opportunity to reduce production costs [11].

Several processes are currently employed for homogeneous catalytic transesterification, although these processes suffer from the presence of by-products that reduce selectivity and increase the separation time between products, while recently heterogeneous catalysts have been claimed to produce cleaner processes. In any of those situations, when the reaction is carried out under microwaves, transesterification is efficiently activated, with short reaction times, and as a result, a drastic reduction in the quantity of by-products and a short separation time is obtained, and all with a reduced energy consumption.

Several examples of microwave irradiated transesterification methods have been published in the literature, by Loupy [1] and Mazzocchia [12], but they have made use of batch laboratory ovens, which do not allow to study the process at a higher scale. Similar results have been described by adapting domestic ovens to use them as flow systems $[13,14]$. A recent paper from Leadbeater describes the use of two batch laboratory microwave apparatus, one monomode to perform micro experiments, the other multimode able to irradiate flasks up to $5 \mathrm{~L}$ [15]. Some 
microwave flow prototypes have been described in recent patents $[16,17]$.

\section{Experimental method}

\subsection{Reagents}

Tests of transesterification were performed either with commercial rapeseed, or soybean oil from Aceites Albert S.A. (Valencia, Spain). Methyl $t$-butyl ether (MTBE), sodium hydroxide (98\%), phosphoric acid ( $85 \%$ ) and methanol $(98 \%)$ were purchased from Aldrich. An average value of 884 was taken as a molecular weight of the oil.

\subsection{Apparatus}

All batch microwave tests have been conducted with a CEM Explorer PLS, while the flow microwave experiments have been performed with a CEM Voyager [14], both single mode operating systems, working at $2.45 \mathrm{GHz}$, with a power programmable from 1 to $300 \mathrm{~W}$. Stirring was performed at $400 \mathrm{rpm}$, with a magnetic nucleus, because the apparatus cannot modulate the speed, not to emulsify and disperse the methanol in oil, but solely to make the mixture temperature homogeneous. Tests were conducted with the ratio methanol/oil of $9 / 1,18 / 1$ and 30/1.

\subsection{Experimental procedures and analysis}

\subsubsection{Microwaves batch tests}

In a standard CEM $10 \mathrm{ml}$ pressurised reaction vial, $\mathrm{NaOH}(0.013-0.04 \mathrm{~g}, \quad 0.325-1 \mathrm{mmol})$ was dissolved in $\mathrm{MeOH}(1.33-2.66 \mathrm{~mL}, 1.05-2.1 \mathrm{~g}, 32.77-2.655 \mathrm{mmol})$, then, the corresponding oil $(2.50-3.26 \mathrm{~mL}, 2.30-3.0 \mathrm{~g}, 1.327-$ $3.394 \mathrm{mmol}$ ) and methyltertbutyl ether (MTBE) $(2.72 \mathrm{~mL})$ were added. The vial was tapered with a cap and irradiated at $60{ }^{\circ} \mathrm{C}$ for $1-60 \mathrm{~min}$, with stirring $(400 \mathrm{rpm})$. After allowing the mixture to cool to room temperature, $\mathrm{H}_{3} \mathrm{PO}_{4}(85 \%$, $0.0375-0.1553 \mathrm{~g}, 0.022-0.068 \mathrm{mmol}$ ) was added. The solid formed was filtered off and the organic solvents were removed by vacuum distillation. The residue was treated in an Eppendorf 5804R centrifuge, to remove the glycerol layer: Then, the sample was extracted with $1 \mathrm{~mL}$ of water, dried with $\mathrm{Na}_{2} \mathrm{SO}_{4}$, weighed and analysed.

\subsubsection{Conventional heating tests}

In a $50 \mathrm{~mL}$ round-bottomed flask, with magnetic stirring, $\mathrm{NaOH}(0,13 \mathrm{~g}, 3.25 \mathrm{mmol})$ was dissolved in $\mathrm{MeOH}$ $(5.52 \mathrm{ml}, 4.37 \mathrm{~g}, 136.27 \mathrm{mmol})$, then, the corresponding oil $(10.87 \mathrm{~mL}, 10 \mathrm{~g}, 11.31 \mathrm{mmol})$ and $\operatorname{MTBE}(11.8 \mathrm{~mL})$ were added. The mixture was heated to $60^{\circ} \mathrm{C}$ for $1 \mathrm{~min}$, with stirring $(600 \mathrm{rpm})$. After allowing the mixture to cool to room temperature, $\mathrm{H}_{3} \mathrm{PO}_{4}(85 \%, 0.22 \mathrm{~mL}, 0.375 \mathrm{~g}$, $3.25 \mathrm{mmol}$ ) was added. The solid formed was filtered off and the organic solvents were removed by vacuum distillation. The residue was treated in an Eppendorf 5804R centrifuge, to remove the glycerol layer: then, the sample was extracted with $10 \mathrm{~mL}$ of water, dried with $\mathrm{Na}_{2} \mathrm{SO}_{4}$, weighed and analysed.

\subsubsection{Microwaves flow tests}

Two stock solutions were prepared: one (A) containing oil $(800 \mathrm{~mL}, 736 \mathrm{~g}, 0.832 \mathrm{~mol})$ and MTBE $(672 \mathrm{~mL})$, the other (B) containing $\mathrm{NaOH}(9.6 \mathrm{~g}, 0.24 \mathrm{~mol})$ dissolved in $\mathrm{MeOH}(404.5 \mathrm{~mL}, 320 \mathrm{~g}, 10 \mathrm{~mol})$. The apparatus, working with a cell of $50 \mathrm{ml}$ in stop-flow regime, runs sequential series of operations, repeating the optimal batch procedure. Initially, $34 \mathrm{~mL}$ of $\mathrm{A}(2.89 \mathrm{~mL} / \mathrm{s})$ and $9 \mathrm{~mL}$ of $\mathrm{B}(2.99 \mathrm{~mL} / \mathrm{s})$ were pumped into the flow cell; then, the cell was irradiated, with stirring ( $400 \mathrm{rpm}$ ), at $60{ }^{\circ} \mathrm{C}$ for $1 \mathrm{~min}$. The mixture was allowed to cool for $3 \mathrm{~min}$, and then, the sequence started again. The mixture was treated as indicated in the batch tests, to get an aliquot of it analysed.

\subsubsection{Analysis}

The products were analysed by a FID gas chromatograph (Varian CP 3800) using the official standard methods [19]. The analysis of FAME 2 was made using a column cp $\max 52 \mathrm{CB}, 30 \mathrm{~m}$ long, with ID of $0.32 \mathrm{~mm}$ and $0.25 \mu \mathrm{m}$ film. Temp. ramp starting with $75^{\circ} \mathrm{C}$, then heating $16^{\circ} \mathrm{C} /$ min up to $140{ }^{\circ} \mathrm{C}$, and then $15^{\circ} \mathrm{C} / \mathrm{min}$ up to $300^{\circ} \mathrm{C}$. The analysis of glycerides $3, \mathbf{4}, \mathbf{5}$ and glycerol $\mathbf{6}$ was made using a column W COT fused silica $10 \mathrm{~m}$ long, ID of $0.32 \mathrm{~mm}$ and $0.10 \mu \mathrm{m}$ film. Temperature ramp starting at $50^{\circ} \mathrm{C}$, then heating $20^{\circ} \mathrm{C} / \mathrm{min}$ up to $180^{\circ} \mathrm{C}$, then heating $10^{\circ} \mathrm{C} /$ min up to $230^{\circ} \mathrm{C}$ and finally $15^{\circ} \mathrm{C} / \mathrm{min}$ up to $370^{\circ} \mathrm{C}$. In both methods, hydrogen was used as carrier at $80 \mathrm{KPa}$, and the injection volume was $1 \mu \mathrm{L}$.

\section{Results and discussion}

\subsection{Batch tests}

The overall transesterification process (Scheme 1) was performed as a set of operations as indicated in Scheme 2. To obtain a homogeneous system, the reagents - oil and methanol - were mixed with MTBE as a safe solvent which can be easily recovered and reused. Then, the mixture was irradiated with microwaves, acidified with phosphoric acid, and distilled to eliminate the volatiles - mainly methanol and MTBE - and then, the residue was centrifugated and washed with water, to eliminate the glycerol, and the remaining biodiesel was dried and analysed.

As it can be seen in Table 1, experiments 13 and 14, made either with rapeseed or soybean oil, respectively, where allowed to obtain biodiesel within standards, in terms of the contents of contaminants $\mathbf{3}, \mathbf{4 , 5}$ and glycerol $\mathbf{6}$. No substantial differences were obtained with the different origin of the oil. The best results were obtained when the corresponding oil $(2.3 \mathrm{~g}), \mathrm{NaOH}, \quad(30 \mathrm{mg}), \quad \mathrm{MeOH}$ $(1.27 \mathrm{~mL})$, MTBE $(2.1 \mathrm{~mL})$ were placed in a sealed tube with magnetic stirring. The mixture was heated for $1 \mathrm{~min}$ at $60{ }^{\circ} \mathrm{C}$. The temperature was fixed, so the irradiation 


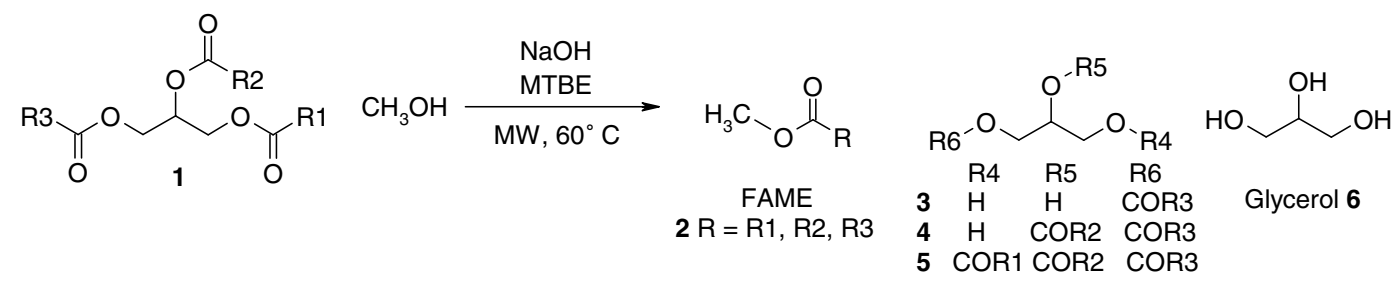

Scheme 1.

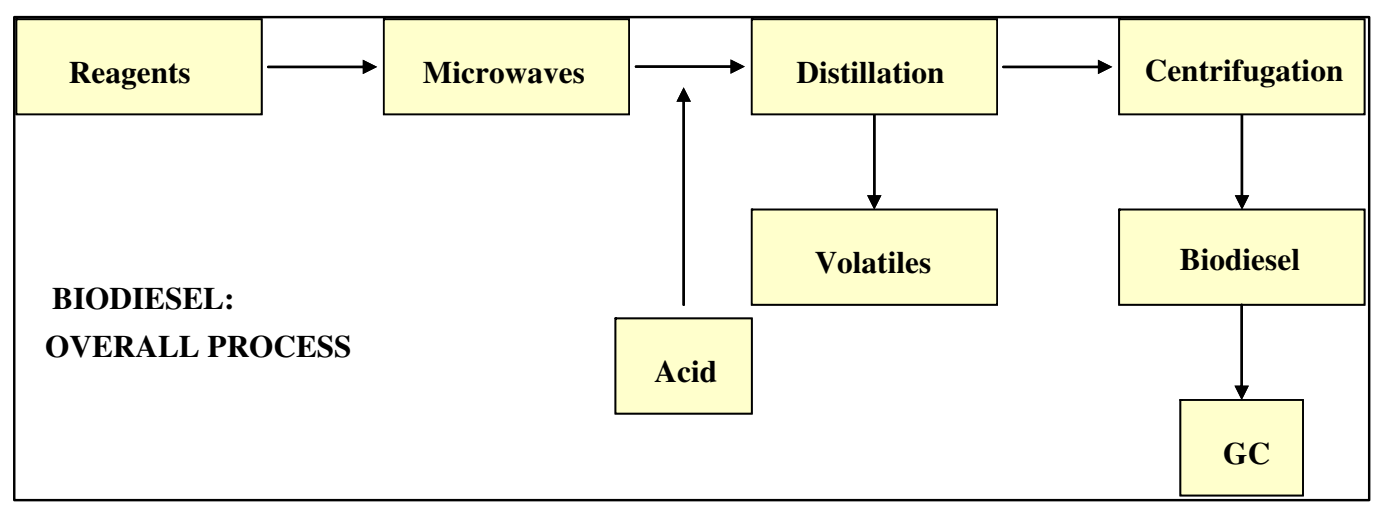

Scheme 2 .

Table 1

Batch tests performed with microwaves to obtain biodiesel

\begin{tabular}{|c|c|c|c|c|c|c|c|c|c|c|}
\hline \multirow[t]{2}{*}{ Entry no. } & \multirow[t]{2}{*}{ Mode } & \multirow[t]{2}{*}{ Oil (g) } & \multirow[t]{2}{*}{$\mathrm{NaOH}(\mathrm{g})$} & \multirow[t]{2}{*}{$\mathrm{MeOH}(\mathrm{mL})$} & \multirow[t]{2}{*}{$t^{\mathrm{c}}(\min )$} & \multirow[t]{2}{*}{ Yield (\%) } & \multicolumn{4}{|c|}{ Other components } \\
\hline & & & & & & & $3(\%)$ & $4(\%)$ & $5(\%)$ & $6(\%)$ \\
\hline 1 & MW & $3.0^{\mathrm{a}}$ & 0.018 & 0.83 & 1 & 17 & 0.50 & 1.81 & 35.53 & 0.04 \\
\hline 2 & MW & & & & 5 & 8 & 0.37 & 1.28 & 42.95 & 0.05 \\
\hline 3 & MW & $3.0^{\mathrm{a}}$ & 0.03 & 0.83 & 1 & 92 & 7.22 & 3.66 & 2.84 & 0.053 \\
\hline 4 & MW & & & & 5 & 92 & 9.74 & 2.01 & 1.17 & 0.11 \\
\hline 5 & MW & $3.0^{\mathrm{a}}$ & 0.04 & 0.83 & 1 & 95 & 2.26 & 0.46 & 0.24 & 0.0005 \\
\hline 6 & MW & & & & 5 & 94 & 1.36 & 0.37 & 0.19 & 0.04 \\
\hline 7 & MW & $3.0^{\mathrm{a}}$ & 0.018 & 1.66 & 1 & 92 & 6.19 & 0.46 & 0.56 & 0.05 \\
\hline 8 & MW & & & & 5 & 92 & 1.92 & 0.01 & 0.02 & 0.06 \\
\hline 9 & MW & $2.3^{\mathrm{a}}$ & 0.03 & 1.27 & 1 & 95 & 0.95 & 0.03 & 0.0006 & 0.03 \\
\hline 10 & MW & & & & 5 & 95 & 0.89 & 0.02 & 0.0003 & 0.03 \\
\hline 11 & MW & $2.3^{\mathrm{a}}$ & 0.03 & 1.27 & $1^{\mathrm{d}}$ & 94 & 0.91 & 0.02 & 0.004 & 0.036 \\
\hline 12 & MW & & & & $5^{\mathrm{d}}$ & 92 & 1.29 & 0.03 & 0.01 & 0.154 \\
\hline 13 & MW & $2.3^{\mathrm{d}}$ & 0.03 & 1.27 & 1 & 97 & 0.48 & 0.03 & 0.012 & 0.007 \\
\hline 14 & MW & $2.3^{\mathrm{b}}$ & 0.03 & 1.27 & 1 & 95 & 0.73 & 0.05 & 0.02 & 0.0008 \\
\hline 15 & MW & $2.3^{\mathrm{b}}$ & 0.03 & 1.27 & $1^{\mathrm{d}}$ & 95 & 1.09 & 0.02 & 0.008 & 0.036 \\
\hline 16 & $\mathrm{CH}$ & $10^{\mathrm{a}}$ & 0.13 & 5.52 & 5 & 84 & 2 & 0.60 & 0.30 & 0.20 \\
\hline 17 & & & & & 30 & 87 & 1.5 & 0.35 & 0.20 & 0.15 \\
\hline EN 14214 & & & & & & & $<\mathbf{0 . 8 0}$ & $<\mathbf{0 . 2 0}$ & $<\mathbf{0 . 2 0}$ & $<\mathbf{0 . 0 2}$ \\
\hline
\end{tabular}

Notes: In the process, the corresponding oil is mixed with methanol and $\mathrm{NaOH}$. MW, experiments performed with microwaves, $2.1 \mathrm{~mL}$ of MTBE were added and the mixture irradiated at $60^{\circ} \mathrm{C}$. $\mathrm{CH}$, experiments performed by conventional heating, $9.1 \mathrm{~mL}$ of MTBE were added and the mixture heated at $60{ }^{\circ} \mathrm{C}$, for the time indicated $(t)$. Yield and composition of the mixture, as obtained by GC.

${ }^{\text {a }}$ Rapeseed oil.

${ }^{\mathrm{b}}$ Soybean oil.

c Reaction time in minutes.

${ }^{\mathrm{d}}$ Power Max was used, to cool externally the reaction tube.

energy was automatically controlled by the apparatus to keep the system within the established temperature limits.
Then, the mixture followed the process as indicated in Scheme 2. 
Table 2

Flow tests performed with microwaves to obtain biodiesel

\begin{tabular}{|c|c|c|c|c|c|c|c|c|c|}
\hline \multirow[t]{2}{*}{ Entry no. (no. cycles) } & \multirow[t]{2}{*}{ Oil (g) } & \multirow[t]{2}{*}{$\mathrm{NaOH}(\mathrm{g})$} & \multirow[t]{2}{*}{$\mathrm{MeOH}(\mathrm{mL})$} & \multirow[t]{2}{*}{$t(\min )$} & \multirow[t]{2}{*}{2 Yield $(\%)$} & \multicolumn{4}{|c|}{ Other components } \\
\hline & & & & & & $3(\%)$ & $4(\%)$ & $5(\%)$ & $6(\%)$ \\
\hline $18(3)$ & $18.4^{\mathrm{b}}$ & 0.24 & 10.16 & 1 & 96 & 0.71 & 0.06 & 0.0010 & 0.008 \\
\hline $19(17)$ & $18.4^{\mathrm{b}}$ & 0.24 & 10.16 & 1 & 97 & 0.60 & 0.03 & 0.019 & 0.016 \\
\hline EN 14214 & & & & & & $<\mathbf{0 . 8 0}$ & $<\mathbf{0 . 2 0}$ & $<\mathbf{0 . 2 0}$ & $<\mathbf{0 . 0 2}$ \\
\hline
\end{tabular}

Notes: In the process, every cycle was performed as follows: the corresponding oil was mixed with methanol and sodium hydroxide, in the quantities indicated in the table, and $16.8 \mathrm{~mL}$ of MTBE. Then, the mixture was pumped through the flow cell, with a useful volume of $50 \mathrm{~mL}$, and heated for the time indicated $(t)$. Yield and composition of the biodiesel, as obtained by GC.

${ }^{\mathrm{a}}$ Rapeseed oil.

b Soybean oil.

${ }^{\mathrm{c}}$ Time of irradiation at $60^{\circ} \mathrm{C}$, in min.

To compare microwave and conventional heating, two experiments (16-17) are included in Table 1, in which heating to $60^{\circ} \mathrm{C}$ with an oil bath, with stirring (600 rpm) was performed, reproducing the conditions of the experiments 13 and 14. The samples reached an equilibrium after $30 \mathrm{~min},(87 \%$ FAME) and no improvement in yield was obtained after this period.

\subsection{Flow tests}

A CEM Voyager flow system [18] was used to show how the optimal batch method could be scaled up to be converted into a production method. The volumes and quantities of the experiment 14 in Table 1 were multiplied by 8 , to be reproduced in the flow cell of $80 \mathrm{~mL}$ - useful $50 \mathrm{~mL}-$ under a stop-flow regime. Homogeneous phase is the best choice to easily reproduce a method in the system. An aliquot of the mixture was used to follow Scheme 2. The composition of the biodiesel obtained was analysed as indicated in experimental, according present standards [19]. As it can be seen in Table 2, soybean oil was used to reproduce the experiment 14 of Table 1 . Two experiments were made, one with 3 cycles (exp. 18, $55 \mathrm{ml}$ of oil treated) and the other with 17 cycles (exp. 19, 312,8 mL of oil treated). In both experiments, the biodiesel obtained was under the quality standards (Table 2).

\section{Conclusion}

As a conclusion, microwave irradiation has revealed faster and cleaner than conventional heating in the synthesis of FAME (biodiesel) from triglycerides, even in the presence of homogeneous catalysts. The use of modern commercial devices allows to straightforward transfer of the process from batch to stop-flow. This opens the way to develop microwave procedures for a big scale biodiesel production.

\section{Acknowledgement}

Authors acknowledge E. Ruiz and A.I. Cañadas for technical assistance in the experiments.

\section{References}

[1] Loupy A, Petit A, Ramdani M, Yvanaeff C, Majdoub M, Labiad B, et al. Can J Chem 1993;71:90.

[2] Silver RS, Hasenhuettl GL. US Pat. 5,596,085.

[3] Granbreg EP, Schafermeyer RG, Letton JA. PCT/US Pat. 96/07799.

[4] Ahn E, Koncar M, Mittelbach M, Marr R. Separ Sci Tech 1982;30:2021.

[5] Vicente G, Martinez M, Aracil J. Bioresour Technol 2004;92:297 and literature cited therein.

[6] Boehman AL. Fuel Process Technol 2005;86:1057.

[7] Knothe G, Sharp CA, Ryan TV. Energ Fuel 2006;20:403.

[8] Szybist JP, Kirby SR, Boheman AL. Energ Fuel 2005;19:1484.

[9] Vicente G, Martinez M, Aracil J. J Am Oil Chem Soc 2005;86:1057.

[10] Eerée T, Peter S, Weidner E. Ind Eng Chem Res 2005;44:9535.

[11] Serio MD, Ledda M, Cozzolino M, Minutillo G, Tesser R, Santacesaria E. Ind Eng Chem Res 2006;45:3009.

[12] Mazzocchia C, Modica G, Nannicini R, Kaddouri A. CR Chimie 2004;7:601.

[13] Saiffudin N, Chua KH. Malaysian J Chem 2004;6:77.

[14] Silva FC, Ferreira VF, Souza MCBV. Quim Nova 2006;29:376.

[15] Leadbeater NE, Stencel LM. Energ Fuel 2006;20:2281.

[16] Breccia FA WO2003014272 A3. Chem Abs 138:172236.

[17] Portnoff MA, Purta DA, Nasta MA, Zhang J, Pourarian F. US 2005/ 0274065 A1. Chem Abs 144:24718.

[18] Microwave CEM Explorer (batch) and CEM Voyager (flow) reactors were used in the project. The temperature was fixed at $60^{\circ} \mathrm{C}$, so the irradiation energy was limited by the temperature control. The flow system works in stop-flow regime, thus facilitating the reproduction of the optimal batch conditions in the flow system.

[19] Norms EN14214 and EN14103 describe biodiesel requirements and official tests. 